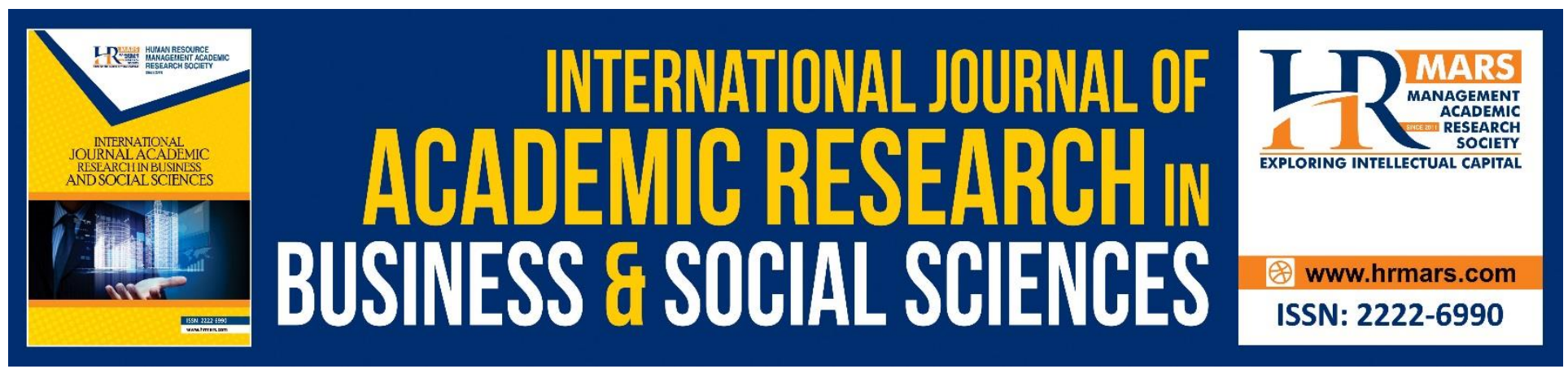

\title{
Demographic Factors of Family Takaful Demand: A Literature Review
}

Fauzilah Salleh, Asyraf Afthanorhan

To Link this Article: http://dx.doi.org/10.6007/IJARBSS/v8-i12/5060

DOI: $10.6007 /$ IJARBSS/v8-i12/5060

Received: 22 Nov 2018, Revised: 17 Dec 2018, Accepted: 25 Dec 2018

Published Online: 29 Dec 2018

In-Text Citation: (Salleh \& Afthanorhan, 2018)

To Cite this Article: Salleh, F., \& Afthanorhan, A. (2018). Demographic Factors of Family Takaful Demand: A Literature Review. International Journal of Academic Research in Business and Social Sciences, 8(12), 613621.

Copyright: (C) 2018 The Author(s)

Published by Human Resource Management Academic Research Society (www.hrmars.com)

This article is published under the Creative Commons Attribution (CC BY 4.0) license. Anyone may reproduce, distribute, translate and create derivative works of this article (for both commercial and non-commercial purposes), subject to full attribution to the original publication and authors. The full terms of this license may be seen

at: http://creativecommons.org/licences/by/4.0/legalcode

Vol. 8, No. 12, 2018, Pg. 613 - 621

http://hrmars.com/index.php/pages/detail/IJARBSS

JOURNAL HOMEPAGE

Full Terms \& Conditions of access and use can be found at http://hrmars.com/index.php/pages/detail/publication-ethics 


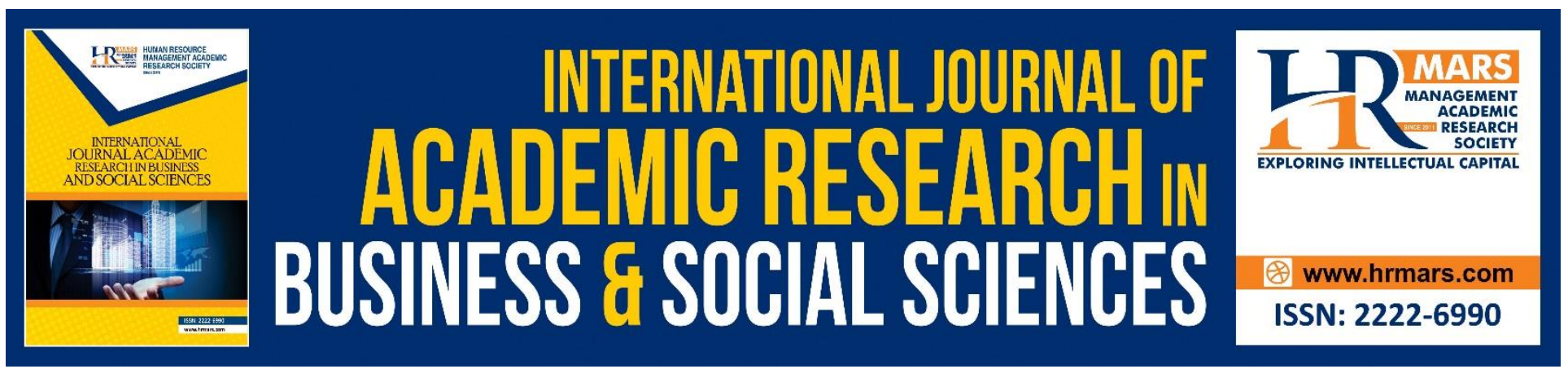

\title{
Demographic Factors of Family Takaful Demand: A Literature Review
}

\author{
Fauzilah Salleh, Asyraf Afthanorhan \\ Faculty of Economics and Management Sciences, Universiti Sultan Zainal Abidin (UniSZA)
}

\begin{abstract}
The purpose of this study is to examine the relationship between family takaful demand and demographic factors. Based on 50 relevant articles from year 2007 until 2017 in Malaysia, 20 of them were found to relate to the demographic factors that affected demand of family takaful. The results of this study were divided into five (5) frequencies, specifically gender $4 / 20$, religiosity $5 / 20$, age $6 / 20$, level of education $11 / 20$, and income $12 / 20$. Therefore, financial income was the most important demographic factor in increasing the demand of family takaful.
\end{abstract}

Keywords: Takaful Industry, Family Takaful, General Takaful, Demographic Factor, Malaysia

\section{Introduction}

Bank Negara defines takaful as an Islamic concept of insurance. It allows a group of participants to guarantee against future loss or damage as mutually agreed by contributing tabarru' in the takaful funds based on the principles of taawun' (mutual assistance) and tabarru' (voluntary contribution). Basically, takaful involves elements of donation and it is free from gharar, maysir, and riba.

Takaful industry is one of the service sectors that determines the economic development of a country. Consider takaful industry provides protection to policy buyers, its growth rate in Malaysia is higher than other Muslim countries such as Indonesia and Bahrain. In Malaysia, takaful industry shows improvement in the number of family takaful operator (Yazid et.al 2012), subsequently gives expansion opportunities for takaful market share, at the same time increases penetration.

According to Hashim (2012), family takaful in Malaysia has low market penetration rate compared to the conventional life insurance market. However, the total market penetration and shared performance in takaful industry lag far behind. In response to this issue, this study is to identify the possible factors that influence the demand of family takaful products and discover the reasons why the public has no interest in family takaful. The objective of this study is to examine the relationship between demographic factors and the family takaful demand. 


\section{Literature Review}

Every individual has the potential to be exposed to different risks. For example, financial losses, damages on property, death through accident, fire, and business. Undeniably, all the Muslims believe in Qadhar. In Islamic teaching, those troubles and adversities can be reduced through participation in family takaful scheme. In Islamic system, takaful can bring equality to all participants. On contrary, the risk in conventional insurance is shouldered by policy holders. All in all, the main goal of takaful is to share profits instead of earning profit from losses (Hussain, 2011).

\section{Takaful Industry}

Takaful industry has been well-established in Malaysia in the 1980s, with various products being offered by takaful operators to meet the market demand. According to Salleh (2015), family takaful products dominated the net contribution share by 78 percent while general takaful dominated 60 percent from the insurance market.

From year 2004 to 2009, there was a significant development of takaful through the average annual growth rate of total assets and contributions from $20 \%$ to $26 \%$. Moreover, takaful market penetration rate also increased from $5.7 \%$ in 2005 to $7.5 \%$ in 2008 . During this period, the total amount of takaful funds doubled from RM5,878.4 million to RM12,445.4 million. The global takaful contribution reached $\$ 12$ billion in 2011 and $\$ 25$ billion in 2015 (Sherif \& Shaari, 2013). In year 2009, Saudi Arabia is the leading country with a total contribution of $\$ 3.86$ billion, followed by Malaysia with $\$ 1.15$ billion, and the United Arab Emirates with $\$ 640$ million (Abdou, Ali, \& Lister, 2014).

According to Yazid (2012), the number of participants in the family takaful is rather low compared to conventional insurance. For instance, Mohd Razif (2011) claimed that only $10.9 \%$ of $53.5 \%$ of market penetration in Malaysian insurance industry. In this case, it is crucial to understand the factors that can encourage family takaful demand since the market is grossly under-tapped.

\section{Product (General Takaful and Family Takaful)}

There are two types of models adopted in Malaysia. The first model is Mudarabah Model which allows all takaful participants to share profits (or losses) from the undertaking (Maysami \& Williams, 2006). In this model, the operators do not have to pay commission, but they will receive salary paid from the profits made by the company. The sharing of profit and loss between the participants and operators is determined in advance based on the company's developmental stages and earnings. The sharing ratio is approved by the Shariah committee beforehand. The total expenses are borne by the shareholders under Mudarabah.

The second model is Wakalah Model which encourages the surplus of fund investments among participants, referring to the net of the management fees or expenses. In a nutshell, Wakalah fee is paid by the participants from their expenses and salaries, which are considered as contributions. The Shariah Advisory Board of the company determines the Wakalah fee one year before. Furthermore, incentive is given to operators who conduct good governance, while the management fee is paid according to the level of performance. 
INTERNATIONAL JOURNAL OF ACADEMIC RESEARCH IN BUSINESS AND SOCIAL SCIENCES

Vol. 8, No. 12, Dec, 2018, E-ISSN: 2222-6990 C 2018 HRMARS

\section{Demographic Factor}

Age

According to Lo (2011), old people are more aware of takaful. As supported by Husin \& Rahman, (2013), behavioural intentions are influenced by age. However, Hassan, Jusoh, \& Hamid, (2013) indicated those aged between 26 and 40 have great awareness of family takaful.

\section{Gender}

Husin \& Rahman, (2013) claimed that behavioural intention is influenced by gender. Specifically, men are more interested in insurance Husin \& Rahman, (2016), because they have strong financial knowledge as compared to their women counterpart (Chen and Volpe, 2002; Worthington, 2006). Most of the time, females are not involved in major financial matters except wives, mothers, and homemakers (Gait \& Worthington, 2007).

\section{Income}

Hassan, Jusoh, \& Hamid, (2013) asserted that the ownership of Islamic Insurance (Takaful) can be influenced by an individual's income level. In other words, those who earn more have higher disposable income compared to those who earn less. Previous studies also pointed out that income level can be considered as a determinant of life insurance participation (Yazid et al., 2012; Redzuan, Rahman, \& Aidid, 2009; Abdullah, 2012; Husin \& Rahman, 2013). As mentioned by Redzuan (2011), life insurance is an expensive product, an increase in income enables consumers to invest in life insurance.

\section{Education}

Education level is influential on a demand for family takaful (Husin et al., 2016). It is important to emphasise on the level of education, which can create greater awareness of life insurance and family takaful among consumers. Normally, consumers prefer to communicate with takaful agents who have knowledge about takaful concept (Loke et al. 2017). Therefore, knowledge is vital to determine consumer participation in family takaful.

\section{Religiosity}

According to Thaker (2017), religiosity can influence the behavioural intention among Muslims. Theoretically, Person's psychological and physical wellbeing are influenced by consumer religiosity (Dali \& Ridzwan, 2014; Tieman \& Ghazali, 2013). Wilson, (2012) claimed that Muslim consumers with high level of religiosity seek high involvement in Islamic products due to their faith.

\section{THE THEORETICAL FRAMEWORK OF STUDY}

Independent variables such as age, gender, income, education, and religiosity are expected to have a direct impact on family takaful demand as dependent variable. 
INTERNATIONAL JOURNAL OF ACADEMIC RESEARCH IN BUSINESS AND SOCIAL SCIENCES

Vol. 8, No. 12, Dec, 2018, E-ISSN: 2222-6990 C 2018 HRMARS

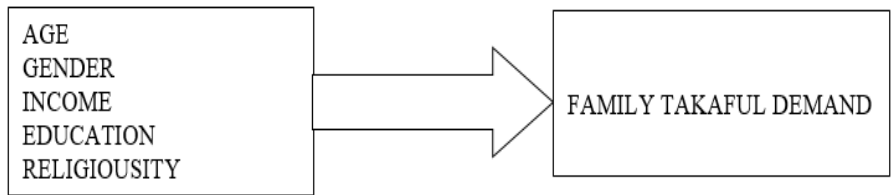

\section{Research Methodology}

Figure 1: The Theoretical Framework

\section{Content Analysis}

This study aims to examine the influence of demographic factors on family takaful demand using quantitative method. Based on a total of 50 articles, it is found that the development of takaful industry is related to family takaful demand. However, this study focuses on demographic factors that affect family takaful demand, which has not been explored by previous researchers.

Figure 1 shows the content analysis process. The process started with sample selection. In the second stage, the unit of analysis was chosen. After that, it talked about the determination of the theme categories by coders. From the categories schemes, the final categories were selected by judges. Finally, the frequency analysis was performed.

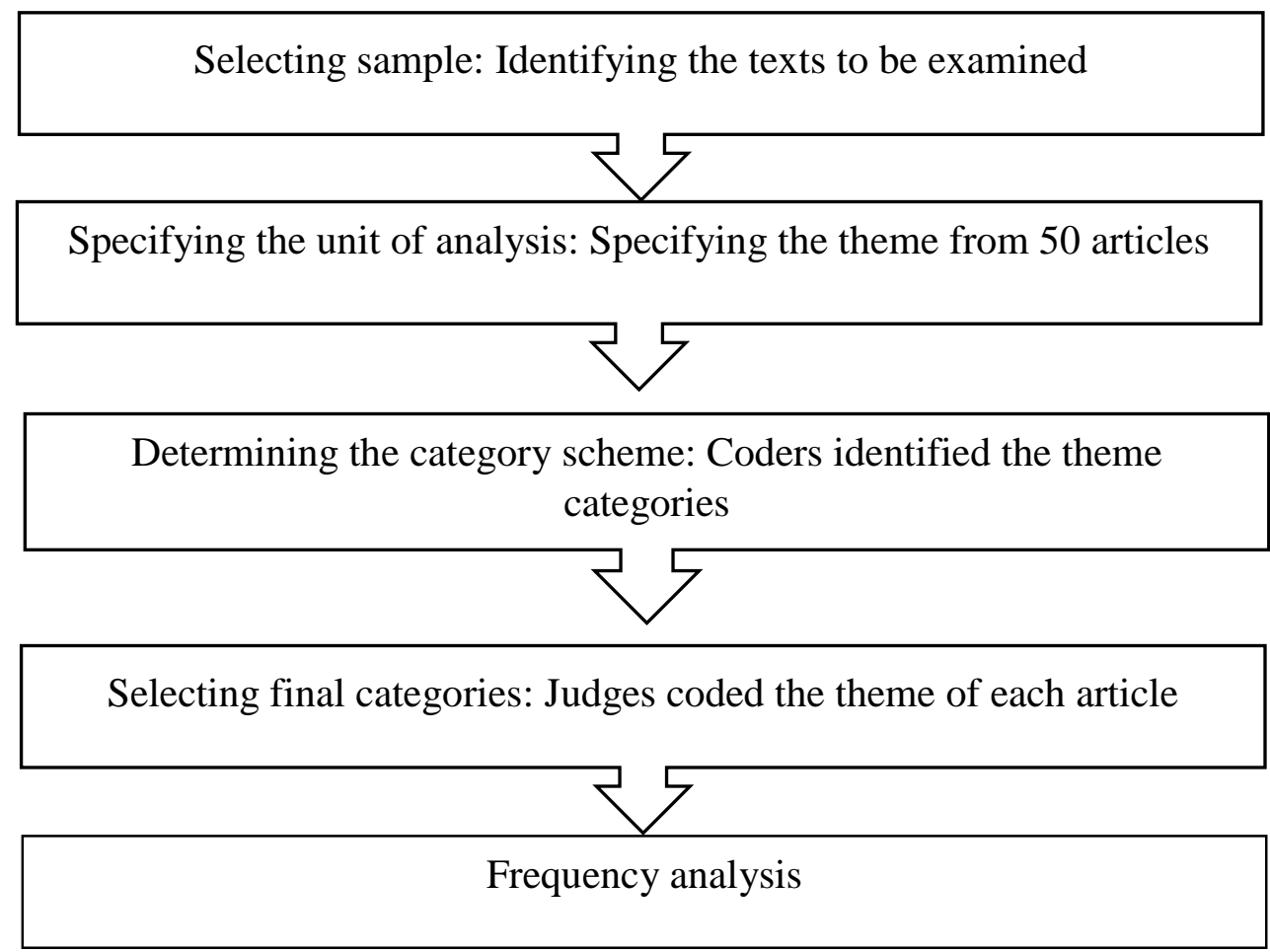


INTERNATIONAL JOURNAL OF ACADEMIC RESEARCH IN BUSINESS AND SOCIAL SCIENCES

Vol. 8, No. 12, Dec, 2018, E-ISSN: 2222-6990 C 2018 HRMARS

\section{Selecting Sample}

The sample included relevant 50 articles chosen from books, scholarly journals, news, and the internet. These articles mainly talked about the family takaful demand and demographic factors such as age, gender, education, income, and religiosity.

\section{Specifying the unit of Analysis}

All selected articles were tabulated according to their database, title, author, year, journal, and abstract. The theme was considered as the unit of analysis to classify those articles in order to determine the main research topics.

\section{Determining the category scheme}

According to the 50 articles, multiple factors are found to influence the family takaful demand. These factors were related to socioeconomic, macroeconomic, social, and demographic. The demographic factors such as age, gender, income, and religiosity were of utmost important.

\section{Selection of final categories}

The factors were age, gender, income, education, and religiosity.

"Age" - Participants of the family takaful from different range of age.

"Gender" - Participants of the family takaful from different genders.

"Income" - Participants from different levels of income.

"Education" - Participants from different levels of education.

"Religiosity" - Participants from different levels of religiosity.

\section{Frequency Analysis}

Frequency analysis was done to find out how frequent the variables were used repeatedly in the articles. This analysis is considered a part of descriptive statistic. The frequency of the variables can determine the strongest factor. Table shows the articles that discuss about the factors influencing the demand of family takaful.

\begin{tabular}{|l|l|}
\hline Factors & Frequency \\
\hline Demographic factors & $20 / 50$ \\
\hline Age & $6 / 20$ \\
\hline Gender & $4 / 20$ \\
\hline Level of education & $11 / 20$ \\
\hline Income & $12 / 20$ \\
\hline Religiosity & $5 / 20$ \\
\hline
\end{tabular}

Of 50 articles, only 20 of them were relevant. Based on these articles, five main factors were identified including age, gender, level of education, and religiosity. A total of 12 articles confirmed that income was the most influence factor. Then, 11 articles affirmed that the second factor was level of education. The third factor was age. In fact, six articles confirmed that age had contributed to the 
INTERNATIONAL JOURNAL OF ACADEMIC RESEARCH IN BUSINESS AND SOCIAL SCIENCES

Vol. 8, No. 12, Dec, 2018, E-ISSN: 2222-6990 C 2018 HRMARS

family takaful demand. The least influential factors were religiosity and gender, which were found from five and four articles, respectively.

\section{Expected Findings}

As indicated by 20 articles reviewed in State of Art (STA), income was the most significant factor that influenced family takaful demand. It was concluded the participation of family takaful scheme is highly reliant on the consumer's knowledge. Conversely, other 50 articles revealed that financial income was the most important demographic variable.

\section{The Important of Family Takaful}

Notably, family takaful provides life protection to the participants. When they sign a contract with takaful operator, they will be protected until the end of the contract or mutuality period of the contract. If the participants suffer from loss during the contractual period, the takaful operator will provide the policy money according to the amount of claim they request. If the participants die during the contractual period, on the other hand, their beneficiaries will get the compensation from the takaful operator. Basically, family takaful policy is made available to individuals aged between 18 until 55. Moreover, those who buy a family takaful policy will get tax relief for RM6000.

In addition, family takaful provides participants future saving. It means that participants do not only contribute to their life protection, at the same time, investment. If accident happens, the participants or their heirs will enjoy the monetary benefits within or after the period of the policy. Example of family takaful plan is endowment policy which gives protection to the participants and beneficiaries in terms of policy money and profit from the investment. If the participants survive after the period of the policy, they will get long-term personal savings.

\section{Conclusion}

The objective of this study is to determine the influence of demographic factor on the participation in the family takaful products in Malaysia. The result indicated that education and income were the most important factors. According to Husin \& Rahman (2013), people become aware of the importance of family takaful products when they are experienced and highly educated. Moreover, men are more interested to participate in takaful as compared to women.

In terms of religiosity, Muslims must use products compliant with Shariah. Besides, highly educated consumers are more likely to purchase insurance and takaful. Given that income is one of the factors that contribute to life insurance and takaful purchase, there is a positive relationship between income and takaful consumption.

Consider that family takaful is getting more intention, this study is significant to the scholars, takaful operators, and public. For researchers, they are exposed to novel knowledge. For takaful operators, they are encouraged to participate in a family takaful scheme because its strategies are appropriate for the target market. Since various groups are interested to study family takaful demand, necessary information is needed for future research. In respect of limitation, this study is hampered by 
INTERNATIONAL JOURNAL OF ACADEMIC RESEARCH IN BUSINESS AND SOCIAL SCIENCES

Vol. 8, No. 12, Dec, 2018, E-ISSN: 2222-6990 @ 2018 HRMARS

insufficient resources to collect the data only from year 2007 to 2017 . Finally, demographic factors cannot be considered as salient determinants of the family takaful demand because there are other possible factors.

\section{REFERENCES}

Abdou, H. A., Ali, K., \& Lister, R. J. (2014). A comparative study of takaful and conventional insurance: empirical evidence from the Malaysian market. Insurance Markets and Companies: Analyses and Actuarial Computations, 5(1), 22-34.

Abdullah, N. I. (2012). Analysis of demand for family Takaful and life insurance: A comparative study in Malaysia. Journal of Islamic Economics, Banking and Finance, 8(4), 67-86.

Abu Hassan, L. F., Wan Jusoh, W. J., \& Hamid, Z. (2013). Determinant of customer loyalty in Malaysian Takaful Industry. Procedia-Social and Behavioral Sciences, 130, 362-370. In 4th International Conference on Marketing and Retailing.

Chen, H. and Volpe, R.P. (2002), "Gender differences in personal financial literacy among college students", Financial Services Review, Vol. 11 No. 3, pp. 289-307.

Dali, M., \& Ridzwan, N. (2014). Islamic credit card users' satisfaction: a comparative study (Doctoral dissertation, Cardiff University).

Gait, A. H., \& Worthington, A. C. (2007). A primer on Islamic finance: Definitions, sources, principles and methods.

Hashim, A. J., \& Hashim, M. K. (2012). Exploring the leadership styles among Takaful agency leaders.

Husin, M. M., \& Ab Rahman, A. (2013). The Role of Brand in the Malaysian Takaful Industry. Sains Humanika, 63(1).

Hussain, M. M., \& Pasha, A. T. (2011). Conceptual and operational differences between general takaful and conventional insurance. Australian Journal of Business and Management Research, 1(8), 23-28.

Loke Ke Wei, K., \& Mohd Thas Thaker, H. (2017). A qualitative inquiry into Islamic home financing: evidence from Malaysia. Qualitative Research in Financial Markets, 9(2), 147-167.

Maysami, R. C., \& Williams, J. J. (2006). Evidence on the relationship between Takaful insurance and fundamental perception of Islamic principles. Applied Financial Economics Letters, 2(4), 229-232.

Md Husin, M., \& Ab Rahman, A. (2013). What drives consumers to participate into family takaful schemes? A literature review. Journal of Islamic Marketing, 4(3), 264-280.

Md Husin, M., \& Ab Rahman, A. (2013). What drives consumers to participate into family takaful schemes? A literature review. Journal of Islamic Marketing, 4(3), 264-280.

Md Husin, M., \& Ab Rahman, A. (2016). Predicting intention to participate in family takaful scheme using decomposed theory of planned behaviour. International Journal of Social Economics, 43(12), 1351-1366.

Md Husin, M., Ismail, N., \& Ab Rahman, A. (2016). The roles of mass media, word of mouth and subjective norm in family takaful purchase intention. Journal of Islamic Marketing, 7(1), 59-73.

Mohd Razif, A. K. (2011). Deputy Governor's Speech at the Launch of ING Public Takaful Ehsan. Retrieved March, 12, 2012. 
INTERNATIONAL JOURNAL OF ACADEMIC RESEARCH IN BUSINESS AND SOCIAL SCIENCES

Vol. 8, No. 12, Dec, 2018, E-ISSN: 2222-6990 C 2018 HRMARS

Redzuan, H. (2011). Analysis Of The Demand For Life Insurance And Family Takaful. Universiti Teknologi Mara Doctor of Philosophy.

Redzuan, H., Rahman, Z. A., \& Aidid, S. S. S. H. (2009). Economic determinants of family takaful consumption: Evidence from Malaysia. International Review of Business Research Papers, 5(5), 193-211.

Salleh, F. (2015). The effect of financial factors on general takaful demand among small and medium entreprises in Malaysia (Doctoral dissertation, University Malaysia Kelantan).

Sherif, M., \& Azlina Shaairi, N. (2013). Determinants of demand on family Takaful in Malaysia. Journal of Islamic Accounting and Business Research, 4(1), 26-50.

Thaker, M. A. B. M. T., \& Thaker, H. B. M. T. (2017). The Behavioural Intention of Investors to Use Islamic Banking's Investment Account Platform (IAP) as A Source of Investment Portfolio: A Structural Equation Modeling Approach. Journal of Islamic Monetary Economics and Finance, 3(1), 113-138.

Tieman, M., \& Che Ghazali, M. (2013). Principles in halal purchasing. Journal of Islamic Marketing, 4(3), 281-293.

Wilson, J. A. (2012). Islamic leadership: bedouins in the boardroom and profiting from prophethoodlessons from John Adair. TMC Academic Journal, 6(2), 48-62.

Yazid, A. S., Arifin, J., Hussin, M. R., \& Daud, W. N. W. (2012). Determinants of family takaful (Islamic life insurance) demand: a conceptual framework for a Malaysian study. International Journal of Business and Management, 7(6), 115.

Yazid, A. S., Razali, A. R., \& Hussin, M. R. (2012). Determinants of enterprise risk management (ERM): A proposed framework for Malaysian public listed companies. International Business Research, 5(1), 80. 